\title{
Truth as the key metaethical category in Kierkegaard
}

\author{
Tibor Mahrik
}

DOI: 10.18355/XL.2018.11.01.04

\begin{abstract}
This study offers interpretative insights into Kierkegaard's thought and his understanding of the term "truth" in metaethical relations. Metaethics, though not explicitly presented and used as a term in Kierkegaard's writings, yet represents the implicit framework of his thinking about the life of man, his responsibility, individual life development, and the teleological anticipation of his existence. The thesis presents the concept of truth as an interdisciplinary overlap of metaphysics, epistemology, and philosophy of the mind that can be identified in various Kierkegaardian works and be related to, so selected writings are being examined here. It turns out that, depending on the concealed intention of the author, different aspects of such interdisciplinary complex emerge in different works, which are permeated into the way how Kierkegaard put the word "truth" into different contexts.
\end{abstract}

Key words: language, pseudonyms, ethics, metaphysics, epistemology, Kierkegaard

\section{Introduction}

Kierkegaardian scholars across the world agree in the claim, that Kierkegaard's philosophical and theological perception of reality in general and that of humanity in particular point to an existential interpretation of the ontological totality of phenomenon, where a single individual plays a key role in the visible part of it, and God plays a more than equal role in the invisible part of that complex. He henceforth struggles with the dynamics of life while at the same time being aware of the paradoxical nature of the universe which has its counterpart in the paradoxical nature of the human individual.

This mysterious relationship between the human and divine is mirrored throughout his writing corpus with different intensity and cognitive accent while dealing with daily issues like a family, a society, a church, a university, a culture, but also with ethical categories like love, hate, forgiveness, responsibility, etc. Kierkegaard did not avoid even heavy epistemological stuff when addressing the potentiality and limits of Socratic reasoning in dialectic relation to God's revelation through the Bible and different historical events with the Jewish national story at its center. Reasonable human life and purposeful existence of a single individual within the scope of all the dimension of the personal, social, political, cultural and religious aspects lies behind Kierkegaard's effort to expose, perceive and explain the dialectic of life with a strong emphasis on ethical frameworks that determine human - and consequently social development (Leskova et al., 2017).

\section{Pseudonyms}

Kierkegaard as a rigorous thinker opened an interesting way of handling the above agenda (Kralik et al., 2013). He used different pseudonyms under which he was able to bring different perspectives into the discourse on the particular subject in view and thus to provide an effective space to embrace human existence as a unity of the temporal and the eternal in a very complex way. One has to, therefore, be careful when interpreting his texts and grasping his editorial aim when reading his books (Pavlikova, 2018). While some scholars ignore the character and significance of pseudonyms in the work of Kierkegaard (Pojman), some others overemphasize his genre and writing style (Mackey), while the third group tries to synthesize both these approaches (Roberts). 
We support the complementary view in this paper. This means that although different pseudonyms enter the thinking stage - including Kierkegaard himself - they are not exclusive in a competition sense, but rather unique in terms of the perspective they bring. On the other hand, their synthesis does not offer the completeness either, since for Kierkegaard there is no system that would be final, ultimate or absolutely comprehensive when relating to life reality. Even his "system of pseudonyms" or complex of perspectives, however numerous they may be, will ever satisfy the quest for ultimate understanding and final explanations of any matters of interest on the human side.

\section{Either/Or}

The voluminous Kierkegaard's work Either/Or was written in 1843. It is composed of two basic parts in which we can see Kierkegaard's analysis of various aestheticethical topics, but religious and philosophical topics are not missing there either. Diapsalmata represents views of an ironical person, and finally, volume two of the work ends with a section entitled Ultimatum where Kierkegaard emphasizes the idea that „Against God, we are always in the wrong“ (Kierkegaard, 1990: 346). This vertical set-up of Kierkegaard's way of thinking is of extreme value as this attitude permeates his writings with no exception. This principle must be taken seriously when considering metaethics according to Kierkegaard.

The concept of truth in this work is connected with Kierkegaard's outlook on the difference between the aesthetic and ethical way of life: „Therefore, only when life is considered ethically does it take on beauty, truth, meaning, continuance; only when a person himself lives ethically does his life take on beauty, truth, meaning, security; only in the ethical life-view are autopathetic doubt and sympathetic doubt allayed." (Kierkegaard, 1990: 271). Kierkegaard does not turn his attention to truth in general, but he elucidates in his work beauty and the good life. An Implicit dimension of truth consists in the tension of an individual's longing which exceeds an aesthetic dimension and calls for an ethical dimension of being. Nevertheless. the ethical stage of life is not „higher,“ but rather „different.“ The two stages of life do not stand in a mutual relationship of contradiction nor implication; they are rather mutually complementary.

\section{Works of Love}

Kierkegaard's work Works of Love written in 1847 contains his „Christian reflections," and deals with works of love and the duties of a man to his (her) neighbors. Works of Love are Kierkegaard's reaction to a Lutheran interpretation and consequences of the distorted doctrine of „sola gratia.“ Kierkegaard in this writing points to the truth in connection with duty. As an example, he presents Jesus Christ who in the Bible has continually been facing the provoking questions of the Pharisees by replies that „contained something the questioner is asked to do" (Kierkegaard, 1998: 97). He sets tasks for those who question him and ,the hypocritical questioner received the answer he deserved, but not the answer he wanted." (Ibid.) Christ connects the truth with the task that becomes a duty for his questioner. Those who ask to get the answer that is appropriate for them, which directs them and shows them what they must do (Kierkegaard, 1998: 96-97). An individual is in his perception of reality" in his interior" confronted with impulses „from without." Duty becomes a challenge for a free decision, action and consequently „way of truth“ which, paradoxically, issues from the truth and also works towards the truth.

Further characteristic attributes of truth in his Works of Love Kierkegaard indicate in his words that „truth must essentially be regarded as a struggle in this world, the world has never been so good and so good it will never become, that the majority

XLinguae, Volume 11, Issue 1, January 2018, ISSN 1337-8384, eISSN 2453-711X 
want the truth or have the true conception of it so that its proclamation could therefore immediately win the approval of all.“ (Kierkegaard, 1998: 366). To speak and „live the truth" one cannot possess truth - one must struggle for it every day, i.e., one must give up one's own comfort - by living for the truth one enters into conflict with the world, with people. Man is confronted by polarity - the truth or the world. For Kierkegaard, therefore, the truth is the highest entity to which man must not give in and must renounce, ,this selfish or cowardly and timorous hankering after winning the approval of other people - as if it were the approval of other people that decide whether something is true or not." (Kierkegaard, 1998: 366-367)

\section{Sickness Unto Death}

In the very first quotation at the beginning of his work from 1843 Kierkegaard stresses that the truth is of God. „Lord, give us weak eyes for things of little worth, and eyes clear-sighted in all of your truth." (Kierkegaard, 1983: 3) The work Sickness Unto Death is religious writing, and one can also be understood as a psychological analysis of the concept of despair: ,If there were nothing eternal in man, he could not despair at all; if despair could consume his self, then there would be no despair at all." (Kierkegaard, 1983: 21) A man without a relationship to God is according to Kierkegaard in a desperate state: „In any case, no human being ever lived, and no one lives outside of Christendom if he is not a true Christian, and insofar as he is not wholly that, he still is to some extent in despair.“ (Kierkegaard, 1983: 22) A feeling of despair contains some element of metaphysical implications that Kierkegaard consequently explains with respect to an individual's subjective experiences.

By giving an account of despair at its maximum and minimum in the section „Despair as consciousness" - Kierkegaard takes his bearings by the vertical relationship of man to God. „The despair that is ignorant of being despair, or the despairing ignorance of having a self and an eternal self“ - „That this condition is nevertheless despair and is properly designated as such manifests what in the best sense of the word may be called the obstinacy of truth. Veritas est index sui et falsi.“ (Kierkegaard, 1983: 42)

Kierkegaard goes on with his indirect criticism of the Christian: ,it is far from being the case that men regard the relationship to truth, relating themselves to the truth, as the highest good ..." (Kierkegaard, 1983: 42). This entails that primary matter for Kierkegaard is a relationship to God to a man that just in it will „discover" the truth and will not be despaired anymore. God stands here as an entity independent of human consciousness and experiences. The horizontal projections of the ethical and religious are in his work organically interconnected with the vertical direction of the truth (Valcova et al., 2016).

\section{Practice in Christianity}

Religious work Practice in Christianity from 1848, which meant for Kierkegaard a more pronounced orientation to Christian topics, uncovers Kierkegaard's interpretation of the relationship of man to the reality of God.

Kierkegaard analyzes the relationship of man towards Jesus Christ who ,is the truth.“ (Kierkegaard, 1991: 159) Man must love Jesus not only in his elevation but also in his abasement. To the truth in this world there belongs suffering as well as victory in the world to come, in the world of truth: „Christ is a composite and yet one and the same, is the abased one and the lofty one." (Kierkegaard, 1991: 160) That is why this truth was for the Jews a stumbling block, and for the non-Jews foolishness. (1 Corinthians $1,23)$

In the third part of the work Practice in Christianity Christ is presented in connection with the truth as follows: ,'From on high,' for when he walked on earth... he also had something else to carry out: he himself had to express the truth with his own life, himself had to portray what it is to be the truth, and as truly human he consequently 
had this something else as his task - to accomplish this himself. So he had something to accomplish himself; he himself learned from what he suffered, learned obedience. $\mathrm{He}$ - to speak altogether humanly and certainly justifiably about a true human being he was developed to become and to be the truth." (Kierkegaard, 1991: 181-182) Christ as the truth becomes a universal principle touching all the people in the sense that the truth is potentially accessible - accordingly from the outlook of an individual; and also in the current sense - because Christ as the truth has realized himself in real life and world.

In the fifth chapter, Kierkegaard deals with the other question connected with the concept of the truth: whether a man can appropriate the truth with the help of somebody else (Kierkegaard, 1991: 205-207). Kierkegaard points out that the person who has conquered the truth, who was suffering and struggling, was Jesus Christ and that is why ,there is no abridgment that leaves out the acquiring of it“", „the way to the truth „cannot be shortened“ (Kierkegaard, 1991: 203 and 207)). He extols Christ's life and points to the contrast between him and „all other human beings.“ (Kierkegaard, 1991: 205) Therefore every generation and every individual must start at the beginning and must acquire a relationship to the truth. The life of an individual becomes and should become a manifestation of inner subjective truth (Ambrozy et al., 2017; Kondrla et al., 2017b)).

\section{Upbuilding Discourses in Diverse Spirits}

Upbuilding Discourses in Diverse Spirits is Kierkegaard's work from 1843 divided into three parts:

\section{Purity of Heart is to will one thing}

What we learn from the lilies of the Field and from the birds of the Air The Gospel of Suffering, Christian Discourses.

Kierkegaard analyses Christ's sufferings and his obedience to God: ,in the fullness of time, he learned obedience from what he suffered" (Kierkegaard, 2009: 253). Kierkegaard contrasts the suffering of Jesus and the fact that he is the truth. „Vinegar could not have been a more acid drink for the Holy One than the scatterbrained attention of the idlers and nauseating sympathy of inquisitiveness when one is the Truth!“ (Kierkegaard, 2009: 254).

In the part of this work called The Joy of It that in relation to God a person always suffers as guilty Kierkegaard is solving the problem of truth as testimony of a human: „When we hear a beautiful, upbuilding, gripping true saying, we usually also ascertain who said it, on what occasion, and in what situation." (Kierkegaard, 2009: 264) He warns that ,a true saying that does not have its truth in the speaker is disheartening, like a blessing that curses the one who is a blessing." (Ibid.) He again stresses unity of thinking and action, here of testimony and pursuit: „In the world of truth there is no difference between a king and a robber; there the only questions asked are whether what he said is truth and whether it was truth in him (Kierkegaard, 2009: 265)

Kierkegaard posits suffering from man against the world: „That bold confidence is able [in suffering] to take power from the world and has the power to change scorn into honor, downfall into victory." (Kierkegaard, 2009: 328) That is the reason why „the good must suffer in the world for the sake of the truth" (Kierkegaard, 2009: 329). In the world ,the righteous have no reward, indeed, are rewarded with scorn and persecution, when the confusion finally becomes so great that people think they are doing God a favor by persecuting the witness to the truth"! (Kierkegaard, 2009: 329) With respect to suffering for the truth which is ,the end" (future contemporaneity before God), stands above such truth which is ,the way" to him (imitation of Christ). 
Paradoxically, though, the priority of the present truth (suffering in the world) is more severe than that of potential truth (eternal disgrace).

\section{Christian Discourses}

Christian Discourses is Kierkegaard's work again published in 1848, and divided into four parts:

The Cares of the Pagans,

States of Mind in the Strife of Suffering

Thoughts that Wound from Behind - for Upbuilding

Discourses at Communion on Fridays.

Truth is dealt with in three passages. Kierkegaard solves the idea of recognition of truth by man. He points to human longing for truth: „It is heard again and again; it is regarded in the world as definitely settled that people would like to know the truth if only they had the capacity and the time for it and if it could be made clear to them." (Kierkegaard, 1997: 170) Then he will immediately refuse this statement: „What a superfluous concern, what an ingeniously fabricated evasion!!“ (Kierkegaard, 1997: 170), and through the fact that he opens room for a deeper delving into this problematic.

According to Kierkegaard ,every human being truly has capacity enough to know the truth," but instead of their use he is making excuses and shoves ,the blame onto the lack of capacity" (Kierkegaard, 1997: 170). The truth is in Kierkegaard connected also with its prerequisite of self-denial, a renunciation which psychologically calls forth a specific attitude: man does not like getting to know it, or he will pertinently reject such a possibility. Kierkegaard demands self-denial, not knowledge. This selfdenial means that man will give up all, pleasure and diversion (Kierkegaard, 1997: 171). Kierkegaard interprets the realization of the truth in its polarity of eternal temporal in the sense that man must deny his own self - die to the world and become an authentic being with all the consequences that this free decision amounts to.

\section{The Book on Adler}

Kierkegaard was inspired by the Danish priest Adolf Peter Adler who claimed that he had received a revelation from Jesus Christ and as a consequence, he lost his job and got retired. After having finished the book in 1846, Kierkegaard worked it over and revised it several times. But with the exception of some, he has never published the book. For Kierkegaard, the concept of truth is part and parcel of the question of truth and the authority of its agent. He points to counterproductive attempts of modern philosophy to rationally prove Christian doctrines and copes with his aversion to „philosophers who call into question divine authority“ (Evans, 2009: 144). Real Christianity Kierkegaard perceives as a religion of transcendence and not of immanence. Both concepts he nevertheless does not relate to an objective description of God's existence but by comparison of a genius and an apostle he points to the way God becomes known to an individual or respectively how a man gets to know Him.

Kierkegaard deals with the metaphysical and existential focus of truth. „An eternal truth remains ,from first to last ... equally true, no more true at its latest moment than at it's first ... it has no relation to the survival as evidence to its truth." (Kierkegaard, 2009a: 36) The human grasp of eternal truth becomes its reduction to „hypothesis“ which it flaunts for years, but in return, it is also liable to annihilation at any moment" (Kierkegaard, 2009a: 36). Therefore it is an untruth. Untruth becomes an ,intrinsic element" of the Socratic reflection of the man in the essence of the thing, and if it is not included in it, the point is just ,illusive superiority in relation to the universal.“ (Kierkegaard, 2009a: 36) A forthright agent of truth does not rely on ,power in the worldly sense“ (Kierkegaard, 2009a: 186), he becomes an individual, refusing a liking 
of the crowd, who are called by God to rely on His Providence as on „Archimedean point ... extra ordinem - et terram movebit" concerning the results of efforts (Kierkegaard, 2009a: 160) An important element of Kierkegaard's conceptual attitude toward truth becomes an „ethical investigation of the concept of Revelation“ (Rosas, 1994: 47) in which he focuses more on the agent of truth than the content of his message.

\section{Judge for yourself}

Kierkegaard already in his initial introduction and prayer of the work from 1852 points to the difference between the world and God: „Well do I know, and I know only all too well, how true it is that the world wants to be deceived." (Kierkegaard, 1991a: 91). On the other hand „Father in heaven! You are Spirit, and they who wish to worship you must worship you in Spirit and truth - but how in Spirit and truth if we are not or do not first of all really strive to become sober! Send, then, your Spirit into our hearts.“ (Kierkegaard, 1991a: 95). For the sphere of the „world“" is according to him a valid discrepancy consisting of a human being: he loves a „lie,“ and at the same time the ,source“" of truth is sought.

Kierkegaard counts truth as something outside the world and man who is relying just on himself cannot in the world either seek or find it. The reason for this is the world - our time or ,the condition of our time is precisely one of having made the infinite and the finite, the highest and the lowest, blend in such a way that the condition is an impenetrable ambiguity“ (Kierkegaard, 1991a: 128). He stresses again how the truth should be brought to bear: „One of two things: either a strenuous life, strenuous in self-denial and renunciation, made strenuous by witnessing in actuality to the truth and against lies (not by declamations amidst seventeen illusions in the quiet hours), and then the claim to Christian dignity; or the more lenient forms, that a pastor's life is no more strenuous than anyone else's, and then a relinquishing of Christian dignity - the two combined are a lie." (Kierkegaard, 1991a: 128)

Kierkegaard criticises the fact that „Christianity became the power in the world" (Kierkegaard, 1991a: 129) the witnesses of the truth did not manage to change the world (Ambrozy et al., 2018; Kondrla et al. 2017), the consequence of their job was just that „Christianity began to be deformed.“ (Ibid.) Kierkegaard demands separation of church and state. The church should not be supported by the state anymore. It can grow only without such support. Then nobody joining church will get any earthly advantages or benefits from the fact that he becomes a Christian, or church member.

\section{The Moment}

Kierkegaard published his journal The Moment in his declining year 1855. For Kierkegaard, it is a characteristic attack on and criticism of formal Christianity on the one hand, and on the other hand, he is stressing and demanding that believers,,suffer for the truth" (Kierkegaard, 2009b: 298). The reason is that only then is a fellow person taking care of his everlasting future - eternal life. Kierkegaard confronts the world that is full of deceit, lies, and immediacy with eternity. By willingness to suffer for the truth, one's life will not be shattered and „,filled with what cannot be recollected eternally" (Kierkegaard, 2009b: 298). Kierkegaard demands that man in truth ought to love just that what causes his own suffering: „Only one thing remains, only one thing is to be recollected eternally - to have suffered for the truth“ and ,his name is written in heaven" (Kierkegaard, 2009b: 299).

„Here in this world the truth which walks in lowliness and abasement has nowhere to lay its head, and must give thanks if someone gives it a glass of water" (Ibid.) - this is again Kierkegaard's highlighting of the truth as Jesus Christ. This truth about suffering for truth one cannot find with priests, called by him „tradespeople“ (Ibid.),

XLinguae, Volume 11, Issue 1, January 2018, ISSN 1337-8384, eISSN 2453-711X 
i.e., those who are trafficking with truth to make a profit of various sorts; one will find the truth in suffering. In that way, Kierkegaard reacts critically to Bishop Martensen, who about that time „began to speak about being truth-witnesses“" (Kierkegaard, 2009b: 98). The personal aspect (agent of truth) plays a more important role, according to Kierkegaard than conceptual aspects of knowledge (Kralik et al., 2017).

\section{On my Work as an Author}

The work On my Work as an Author Kierkegaard wrote in 1851 and clarified in it his mission. Kierkegaard stated: „, Direct communication' is: to communicate the truth directly" to those who are not in truth, who do not know the truth and do not care about it; ",communication in reflection' is: to deceive into the truth" (Kierkegaard, 2009c: 7) Kierkegaard in this work repeatedly stresses that „, the crowd' is untruth“" (Kierkegaard, 2009c: 106). He founds his statements on the Biblical verse (1 Corinthians 9, 24) „Only one reaches the finishing line“ - he reacts by his argumentation that in the Church of his times ,the truth is proclaimed" to hundreds of thousands, but those who „want reach the finishing line“ (Kierkegaard, 2009c: 106) are missing. He explains that further on: ,everyone can and everyone should become this one, but only one reaches the goal“" (Kierkegaard, 2009c: 107). In this way, he has grasped a double meaning: 1. The way of truth is not to be found with the masses. 2 . The truth is connected with the free decision of an individual. Thus he comes to the conclusion that the crowd is not the truth because it is not struggling nor striving for the highest goal: "eternity, which, quiet as the nocturnal sky, arches high over temporality" (Kierkegaard, 2009c: 107). Metaphysical space is being again open while correlating with ethics.

Restated in a more radical way: „The crowd is an untruth. Therefore no one basically has more contempt for what it is to be a human being than those who make a profession of standing at the head of a crowd." (Kierkegaard, 2009c: 108) Thus he opens conflict between the human collective and the individual, siding with the individual. Kierkegaard just stresses the individual: „ethically and religiously the crowd as the authority is an untruth, whereas it is eternally true that everyone can be the one. That is the truth. The crowd is an untruth." (Kierkegaard, 2009c: 109) Kierkegaard holds up as an example Christ who „would not have anything to do with the crowd," but ,wanted to be what he was, the truth, which relates itself to the single individual" (Kierkegaard, 2009c: 109). Kierkegaard brings the idea that man will serve the truth just as a martyr.

It needs to be pointed out that Kierkegaard's assertion is that truth must be grasped as „eternal truth.“ Therefore Kierkegaard refuses politics and political ambitions. (Kierkegaard, 2009c: 109-110) His criticism is also directed at the press. The reason is what is written in an anonymous way and requires ,no discipline, no abstinence, no self-denial“" (Kierkegaard, 2009c: 110). According to Kierkegaard, the truth is concrete and therefore hard-hitting.

\section{Conclusion}

The term "truth" represents a key point for Kierkegaard, from which he develops his metaphysical, epistemological and psychological reasoning in his critical reflections on life, its meaning, and development. The metaphysical understanding of the world and the place of man in it comes for Kierkegaard from the Judeo-Christian narrative about the creation and redemption of man. Jesus Christ as God-Man, respectively God in time is an absolute paradox that represents the ontology of the horizontal and the vertical aspects of human existence, knowledge and the ethical anchor of human moral practice that Kierkegaard was eagerly seeking. In this sense, Kierkegaard strongly stands in the position of an ethical realist whose ethical facts and ethical values have an ontological anchor in time and space. As a cognitivist, he represents 
such an ethical position in which a person as a moral being should strive to perceive the world and himself, while knowledge as such is not an aim but the trigger for right action. The effort of man is to rise out of the love and forgiveness that he essentially experiences in personal relation to God. At that time, the potential of a single individual according to Kierkegaard can be accomplished. It is the development of the personality and the whole of society, in which the authenticity and fear of God create the basis for the cognitive development of man and the appropriate development of society to be sustained against all the odds. These metaethical insights represent the precious inheritance of Kierkegaard's perception of the world, and their urgent moral imperative should not be overlooked in today's ethics discourse.

\section{Bibliographic references}

AMBROZY, M., - KRALIK, R., - MARTIN, J. G. 2017. Determinism vs freedom: Some ethics-social implications. In: XLinguae, vol. 10, n. 4, pp. 48-57. ISSN 13378384 .

AMBROZY, M., - KRALIK, R., - POYNER, J. 2018. The issue of periodization in Wittgenstein's philosophy of religion. In: European Journal of Science and Theology, vol. 14, no. 1, pp. 115-124. ISSN 1841-0464.

AMINEVA, V.R. 2017. Symbolization as a way of art completion in the story by A. Eniki «Unvoiced testament» In: XLinguae, vol. 10 n. 1, pp. 12-24. Cited 1 time. DOI: 10.18355/XL.2017.10.01.02

EVANS, C. S. 2009. Kierkegaard. New York: Cambridge University Press. 206 p. ISBN 978-0-521-70041-2.

KIERKEGAARD, S. 1990. Either/Or. Ed. \& transl. Howard V. Hong \& Edna H. Hong. Part II. Princeton: Princeton University Press. 528 p. ISBN 0-691-02042-6.

KIERKEGAARD, S. 1998. Works of Love. Ed. \& transl. Howard V. Hong \& Edna H. Hong. Princeton: Princeton University Press. 561 p. ISBN 0-691-05916-7.

KIERKEGAARD, S. 1983. Sickness unto Death. Ed. \& transl. Howard V. Hong \& Edna H. Hong. Princeton: Princeton University Press. 201 p. ISBN 0-69-02028-0.

KIERKEGAARD, S. 1991. Practice in Christianity. Ed. \& transl. Howard V. Hong \& Edna H. Hong. Princeton: Princeton University Press. 452 p. ISBN 0-691-02063-9.

KIERKEGAARD, S. 1991a. For Self-Examination/Judge for Yourselves. Ed. \& transl. Howard V. Hong \& Edna H. Hong. Princeton: Princeton University Press. 320 p. ISBN 0-691-02066-3.

KIERKEGAARD, S. 1997. Christian Discourses - The Crisis and a Crisis in the Life of an Actress. Ed. \& transl. Howard V. Hong \& Edna H. Hong. Princeton: Princeton University Press. 512 p. ISBN 0-691-01649-6.

KIERKEGAARD, S. 2009. Practice in Christianity. Ed. \& transl. Howard V. Hong \& Edna H. Hong. Princeton: Princeton University Press. 464 p. ISBN 0-691-14077-4.

KIERKEGAARD, S. 2009a. The Book on Adler. Ed. \& transl. Howard V. Hong \& Edna H. Hong. Princeton: Princeton University Press. 496 p. ISBN 0-691-03226-2.

KIERKEGAARD, S. 2009b. The Moment and Late Writings. Ed. \& transl. Howard V. Hong \& Edna H. Hong. Princeton: Princeton University Press. 776 p. ISBN 0-69114082-0.

KIERKEGAARD, S. 2009c. The Point of View. Ed. \& transl. Howard V. Hong \& Edna H. Hong. Princeton: Princeton University Press. 376 p. ISBN 0-691-14080-4.

KONDRLA, P. - REPAR, P. 2017. Ontological Consequences of the Ethics of Technology. In: Komunikacie, vol. 19, n. 1, pp. 19-24. ISSN 1335-4205.

KONDRLA, P. - TOROK, L. 2017b. Objective faith and weak truth. In: European Journal of Science and Theology, vol. 13, n. 1, pp. 79-86. ISSN 1841-0464.

KRALIK, R. - PAVLIKOVA, M. 2013. The reception of Kierkegaard's work in Slovakia. In: Filozofia, vol. 68, n. 1, pp. 82-86. ISSN 0046-385X.

XLinguae, Volume 11, Issue 1, January 2018, ISSN 1337-8384, eISSN 2453-711X 
KRALIK, R. 2017. Kierkegaard's interpretation of faith. In: XLinguae, vol. 10, n. 3, pp. 37-44. ISSN 1337-8384.

LESKOVA, A. - VALCO, M. 2017. Identity of adolescents and its dimensions in the relation to Mass media: philosophical and ethical reflections. In: XLinguae, vol. 10, n. 3, 324-332. ISSN 1337-8384.

LINEVA, E.A. - SAVELYEVA, E.B. - YUSUPOVA, T.G. 2017. Andre Gide's life philosophy: "Russian trace" XLinguae, vol. 10 n. 3, pp. 184-201. DOI: 10.18355/XL.2017.10.03.15

ROSAS III, L. J. 1994. Scripture in the Thought of Søren Kierkegaard. Nashville: Broadman \& Holman Publishers. 219 p. ISBN 0-8054-1624-2.

PAVLIKOVA, M. 2017. Consciousness of Anxiety in Literary Work of Don DeLillo. In: XLinguae, vol. 10, n. 1, pp. 62-69. ISSN 1337-8384.

PAVLIKOVA, M. 2018. The power of modern technologies in fiction of Don DeLillo. In: Komunikacie, vol. 20, In print. ISSN 1335-4205.

VALCOVA, K. - PAVLIKOVA, M. - ROUBALOVA, M. 2016. Religious existentialism as a countermeasure to moralistic therapeutic deism. In: Komunikacie, vol. 18, n. 3, pp. 98-104. ISSN 0341-2059.

Words: 5063

Characters: 31115 (17,29 standard pages)

PhDr. Tibor Máhrik, PhD.

Faculty of Arts

Constantine the Philosopher University in Nitra

Hodžova 1, 94901 Nitra

Slovakia

tmahrik@ukf.sk 